\title{
Morphological changes and quality of papaya seeds as correlated to their location within the fruit and ripening stages
}

\author{
Alteraciones morfológicas y calidad de semillas de papaya a la correlación con su \\ localización dentro de la fruta y las etapas de maduración
}

\author{
Maristela Aparecida Dias ${ }^{1 *}$, Denise Cunha Fernandes dos Santos Dias ${ }^{2}$, \\ Francisco Guilhien Gomes Junior ${ }^{3}$, Silvio Moure Cícero ${ }^{3}$
}

\begin{abstract}
Papaya seeds presents irregular and slow germination. In this sense, the evaluation of the internal morphology of the seeds may be viable and complementary in evaluating the physiological quality of seed. The objective of this study was to evaluate the morphological and physiological quality of papaya seeds extracted at different ripeness stages of the fruit and the position inside of the fruit. Papaya fruits were harvested at maturity stage 1 and the seeds extracted in stages 1, 3, 5 and full maturation. The fruits were cut into three portions of equal size. Seeds of the central portion and extremities were extracted separately. Were determined: seed germination (\%), dormant seeds (\%), accelerated aging, X-ray test and seedling length. A randomized design factorial was used with four replications. Data were subjected to analysis of variance and treatment means were compared by Tukey test at $5 \%$ probability. The results demonstrated that the post-harvest maturity of fruits improves the physiological quality of papaya seeds, promoting a reduction in the number of dormant and non-viable seeds. High physiological quality seeds is obtained from the central portion of fruits at fifth and final maturation stages, corresponding from $75 \%$ to $100 \%$ of maturation, respectively. The $\mathrm{X}$-ray test proved to be adequate to evaluate the morphological quality of papaya seed, allowing distinguish between empty seeds and seed with normal embryo within a sample.
\end{abstract}

Key words: Carica papaya L., germination, maturation, X-ray.

\section{RESUMEN}

Semillas de papaya presentan germinación irregular y lenta. En este sentido, la evaluación de la morfología interna de las semillas puede constituir una alternativa viable y complementaria en la evaluación de la calidad fisiológica de la semilla. El objetivo de este trabajo fue evaluar las alteraciones morfológicas y la calidad fisiológica de semillas de papaya extraídas en diferentes etapas de la maduración de las frutas y las diferentes posiciones dentro de la fruta. Frutos de papaya fueron cosechados en la etapa 1 de la madurez y las semillas se extrajeron en etapas 1, 3, 5 y final. Las frutas se cortaron en porciones de igual tamaño. Semillas de la porción central y las extremidades se extrajeron por separado. Se determinaron: la germinación de semillas (\%), semillas dormantes (\%), la prueba de envejecimiento acelerado, los rayos X y la longitud de las plántulas. El experimento se realizó en un diseño factorial con cuatro repeticiones. Datos fueron sujetos a análisis de varianza y medios de tratamiento se compararon mediante la prueba de Tukey al $5 \%$ de probabilidad. Los resultados demostraron que la maduración posterior a la cosecha de fruta mejora la calidad de las semillas de papaya, con una reducción en el número de semillas dormantes y no viables. Alta calidad fisiológica de las semillas se obtiene de la parte central de los frutos en la etapa de maduración 5 y final, que corresponde al 75\% y 100\% de la maduración, respectivamente. La prueba de rayos X es adecuada para evaluar la calidad morfológica de las semillas de papaya y permite distinguir entre las semillas vacías y semillas con embrión normal dentro de una muestra.

Palabras clave: Carica papaya L., germinación, maduración, rayos $X$.

1 Instituto Capixaba de Pesquisa, Assistência técnica e Extensão Rural (Incaper), 29375-000. Venda Nova do Imigrante, ES, Brasil.

2 Departamento de Fitotecnia. Universidade Federal de Viçosa.

3 Departamento de Produção Vegetal, ESALQ/USP

* Corresponding author: maristela.dias@ incaper.es.gov.br

Fecha de Recepción: 16 Enero, 2013.

Fecha de Aceptación: 30 Noviembre, 2013. 


\section{Introduction}

The physiological quality of papaya seeds still constitutes an obstacle to farmers, due to their irregular and slow germination. The causes of this problem are not yet fully understood and are attributed to post harvest dormancy or to difficulties in their preservation during storage. Among the problem mentioned are many factors such as: influence of the harvest season on seeds quality (Tokuhisa et al., 2007a); the post-harvest storage of fruits (Martin et al. 2006); the presence of sarcotesta (Tokuhisa et al., 2007a); the presence of inhibitory compounds on the seed structures (Tokuhisa et al. 2007b). Nagao and Furutani (1986), assessing the relative weight and the germination of papaya seeds, belonging the group 'Solo', reported that the lower density seeds (although not showing external differences in relation to the seeds with higher density) did not have a normal embryo, which was verified by incising the seeds. This could also be one of the factors responsible for the low germination of papaya seeds.

In this sense, the evaluation of the internal morphology of papaya seeds may be a viable and complementary alternative to assess their physiological potential. The X-ray test can be used for determining the proportion of seeds wellformed or empty, seeds mechanically damaged or by harmful organisms present in a seed lot, once allows for evaluating their the internal structures (Brasil, 2009).

This test allows the identification of seed morphological changes and correlates their effects on their physiological quality (Dell-Aquilla, 2009). Therefore, it can be used to evaluate seed development during the maturation process, by revealing the embryo and the tissues reservation structures through the features highlighted by radiography (Craviotto et al., 2002; Silva and Nascimento, 2008).

Consequently, the X-ray technique has potential for use in monitoring the ripening process of papaya seeds, also allowing for identifying the presence of malformed, defective or empty seeds within a lot as well as providing additional information regarding their physiological quality. The objective of this study was to use the X-ray test to verify the occurrence of morphological changes in papaya seeds, attributing their effects to the physiological quality of the seeds removed from two different locations within the fruits at distinct ripening stages.

\section{Material and Methods}

Seeds were extracted from hermaphrodite fruits of papaya (Carica papaya L.), hybrid "Tainung 01", field harvested in 2010, in the municipality of Pinheiros, State of Espírito Santos, Brazil (18 $38^{\circ}$ ' latitude $\mathrm{S} ; 40^{\circ} 23^{\prime}$ longitude $\mathrm{W}$; and altitude $122 \mathrm{~m}$ ). The fruits were harvested at the ripening stage 1 (up to $15 \%$ of yellowish fruit surface), and were stored in at room temperature in Laboratory of Seeds Analyses of the Federal University of Viçosa until reaching the ripening stages 3 and 5, and full maturation, corresponding to $50 \%, 75 \%$ (Aroucha et al., 2005), and $100 \%$ of yellow fruit surface, respectively. When these ripening stages were reached, the fruits were cut into three parts of similar sizes. The seeds from the two extremities (proximal and distal) and those located in the central portion of the fruits were removed separately. The sarcotesta was then removed by rubbing the seeds on a wire screen under tap water. Afterward the seeds were dried to about $12 \%$ (w.b.) moisture content at room temperature.

Germination test: four replications of 50 seeds each were placed into rolled paper towels moistened with distilled water at a proportion of 2.5 times the dry substratum weight and allowing for germination at $20-30{ }^{\circ} \mathrm{C}$ and $16 / 8 \mathrm{~h}$ photoperiod, according to Brasil (2009). Results were expressed as means of the normal seedlings percentage obtained at the first counting ( 15 days) and the counts performed at the $30^{\text {th }}$ day after sowing (final germination). For the remaining seeds of the germination test the esclerotesta was carefully removed, thus obtaining the internal structures (endosperm with the embryo).

Tetrazolium test: for this test, the endosperm was longitudinally cut to expose the embryo, which was then immersed into a $0.5 \% 2,3,5$ triphenyl tetrazolium chloride solution, for $12 \mathrm{~h}$, at $35^{\circ} \mathrm{C}$, in the dark, according to preliminary tests. After that period, the solution was drained and the seeds were individually examined under stereomicroscope. Viable seeds (dormant) had embryos with a bright pink color and firm consistency.

Accelerated aging: the seeds were distributed in a single layer on a wire mesh screen maintained over $40 \mathrm{ml}$ of water inside $11 \mathrm{~cm}$ x $11 \mathrm{~cm} \times 3.5 \mathrm{~cm}$ plastic germination boxes (gerbox) (AOSA, 1983). The boxes were kept into an incubator, at $41 \pm 0.5^{\circ} \mathrm{C}$, for $48 \mathrm{~h}$. After that time, four replications of 50 seeds each were evaluated for germination as 
previously described (Brasil, 2009). The evaluation was performed 30 days after seeding and the mean of normal seedlings was computed.

$\mathrm{X}$-ray test: this test was performed in the Seed Image Analysis Laboratory at Escola Superior de Agricultura “Luiz de Queiroz" (ESALQ), Piracicaba, SP, Brazil. After preliminary tests, four replications of 25 seeds each per treatment were radiographed with the aid of digital equipment Faxitron X-ray brand, model MX-20 DC12, connected to the computer. Radiographs were obtained with the seeds placed at a distance of $14.3 \mathrm{~cm}$ from the source of X-ray emission. The X-ray plates were evaluated based on the presence and morphology of the endosperm and embryo. The percent of seeds with the embryo easily visible (EEV), with visible radicle (VR) and apparently empty seeds (AE) were determined.

Seedling length by Seed Vigor Imaging System: seeds previously subjected to X-ray test were germinated on paper, following the same conditions described for the germination test. At 15 days after sowing were recorded percentages of seeds that issued the primary radicle and normal seedlings (germination) and the average length of seedlings determined using the Seed Vigor Imaging System ${ }^{\circledR}$ program(Marcos-Filho et al., 2009).
Experimental design and statistical analysis: the experiment was carried out in a completely randomized experimental design, with four replications. The treatments were arranged into a $2 \times 4$ factorial scheme (two seed sites within the fruit $\mathrm{x}$ four ripening stages). In the ANOVA, the treatment effects were tested by $\mathrm{F}$ test $(\mathrm{P} \leq 0.05)$ and treatment means were compared by Tukey test $(\mathrm{P} \leq 0.05)$ using a SAS software (Statistical Analysis Software).

\section{Results and Discussion}

Data on the interaction between maturity stages and the seed positioning within the fruit indicate that there was been an increase in the seed germination percentage (Figure 1A) with the advance in the ripening of fruits, once the highest values were obtained for seeds from both locations within the fruits at the full maturation stage. Seeds removed from the central portion of the fruits, however, had a higher germination in relation to the extremities, when removed from fruits at the ripening stages 3 , 5 and full maturation.

The first count of germination (Figure 1B) showed higher percentages for the germinated

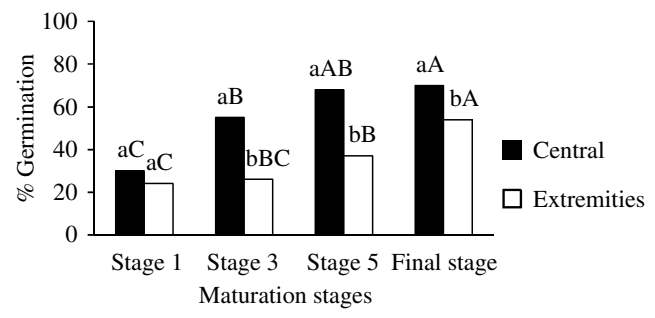

A
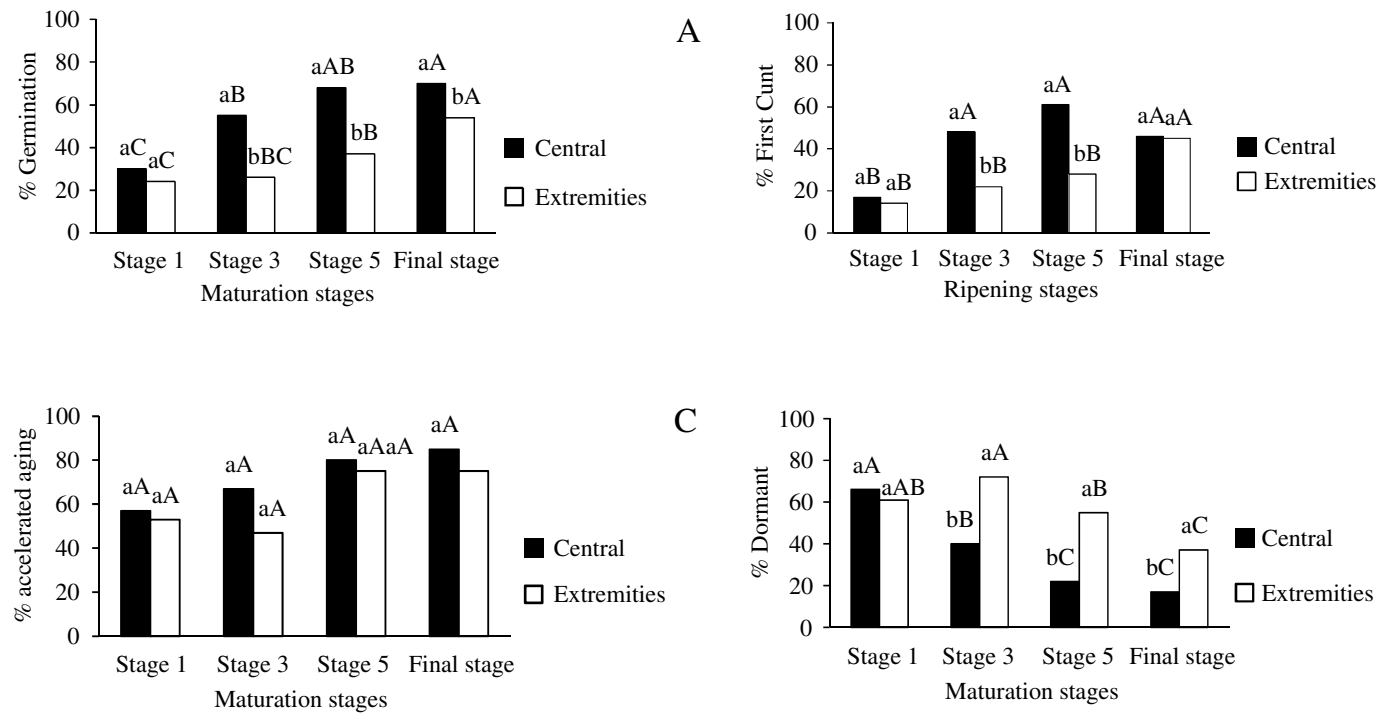

C

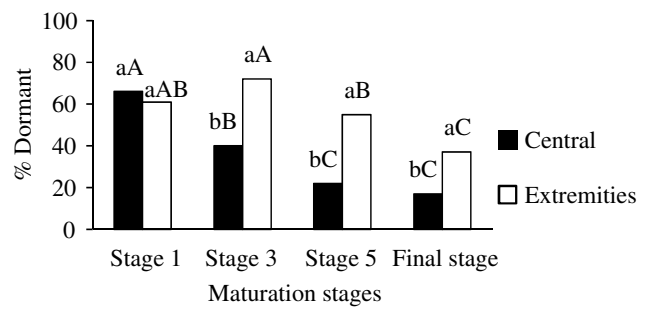

Figure 1. Means percentages of the data obtained in the of germination (A), first count of germination (B), accelerated aging (C) and dormant seeds (D) according to the maturation stages and location of seeds within the fruit (central portion and extremities) of papaya (Carica papaya L.) hybrid "Tainung 01". Means followed by lowercase letters on top of each graph column compare the location of seeds within the fruit at each ripening stage; uppercase letters compare each location among ripening stages. Graph columns topped with the same letter are not statistically different by $\mathrm{F}$ and Tukey tests at $5 \%$ probability, respectively. 
seeds when these were collected from the central portion of the fruits in the ripening stages 3 and 5 . When the seeds were removed from the fruits extremities, the best results were observed in the full maturation stage. The post-harvest storage of fruits promoted a reduction in the dormant seeds percentage (Figure 1D). Higher percentages of dormant seeds were observed for the extremities of the fruits at the ripening stages 3 and 5 and full maturation as compared to those removed from the central portion. There was no significant differences in the germination between the seeds removed from the central portions and the extremities of the fruit at the ripening stage 1 , in the first count of germination. The post-harvest ripening of fruits favored the germination of papaya seeds and this increase was associated with a reduction in the percentage of dormant seeds (Figure 1). Possibly, during the ripening process up to the fifth ripening stage, there was a reduction of the inhibitory compounds and, or synthesis of essential compounds for germination. According to Martins et al. (2006), the reduction of dormancy in papaya seeds during ripening may be related to a balance between germination promoters and inhibitors. In addition, the seeds of fleshy fruits, such as papaya, continue to mature for several days if not removed from the fruit. Beneficial effects of post-harvest storage of fruits on seed quality have already been previously observed in papaya (Aroucha et al., 2005), tomato (Dias et al., 2006; Vidigal et al., 2006) and pepper seeds (Vidigal et al., 2009; Vidigal et al., 2011).
The seed vigor, evaluated by the accelerated aging test (Figure 1C), was similar for all treatments. In general, it was observed that both, germination and seed vigor, increased with the ripening of fruits what was followed by a reduction in the occurrence of dormant seeds. Higher physiological quality of seeds was obtained from the central portions of the fruits at the fifth and full maturation stages (Figure 1). Aroucha et al. (2005) also verified that the post harvest fruit storage was beneficial for papaya seed germination.

From the images generated by applying X-ray on the papaya seeds removed from the extremities of the fruits at the ripening stage 1 , it was found that four seeds (seeds number 11, 13, 15 and 17) were empty in one replication of 25 seeds (Figure 2A) and did not germinate when subjected to germination test (Figure 2B). The same fact was also observed in other replications. Oppositely, for seeds extracted from the central portion of the papaya fruit at maturity stage 1 (Figure 3), the presence of non-germinated seeds in the germination test (Figure 3B) was not correlated with the presence of empty seeds (Figure 3A). This occurred because this class of seeds (empty) was not detected by the X-ray test performed in the seeds removed from the central portion of the fruits, in contrast with what was observed for seeds removed from the fruit extremities (Figure 2A).

In the Figure 3, it can be observed that on the plates of the X-ray test performed on some nongerminated seeds, these had a normal appearance with visible embryonic axis. This can be verified, for

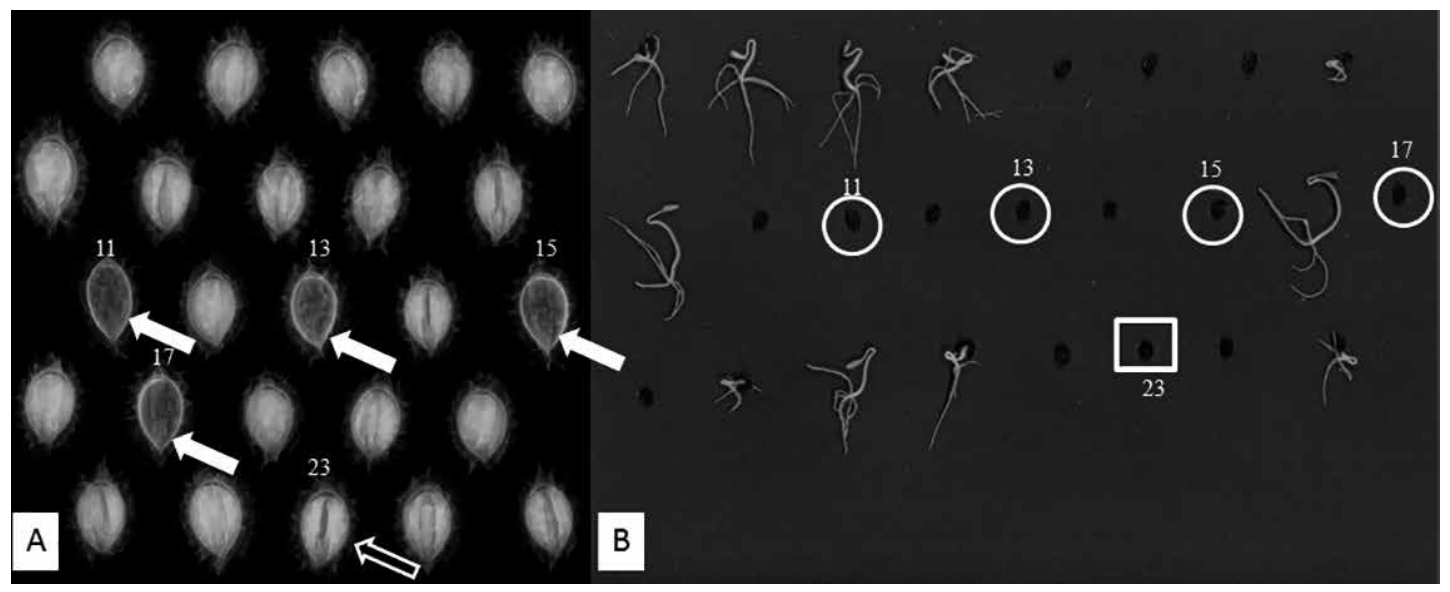

Figure 2. Radiographic image of papaya (Carica papaya L.) hybrid "Tainung 01" seeds extracted from the extremities of the fruits at the ripening stage 1 comparing the seeds number 11,13, 15, and 17 classified as "apparently empty" (AE) with the seed number 23 classified as "embryo easily visible (EEV) (A), and results of the germination test of those seeds 15 days after sowing (B). 


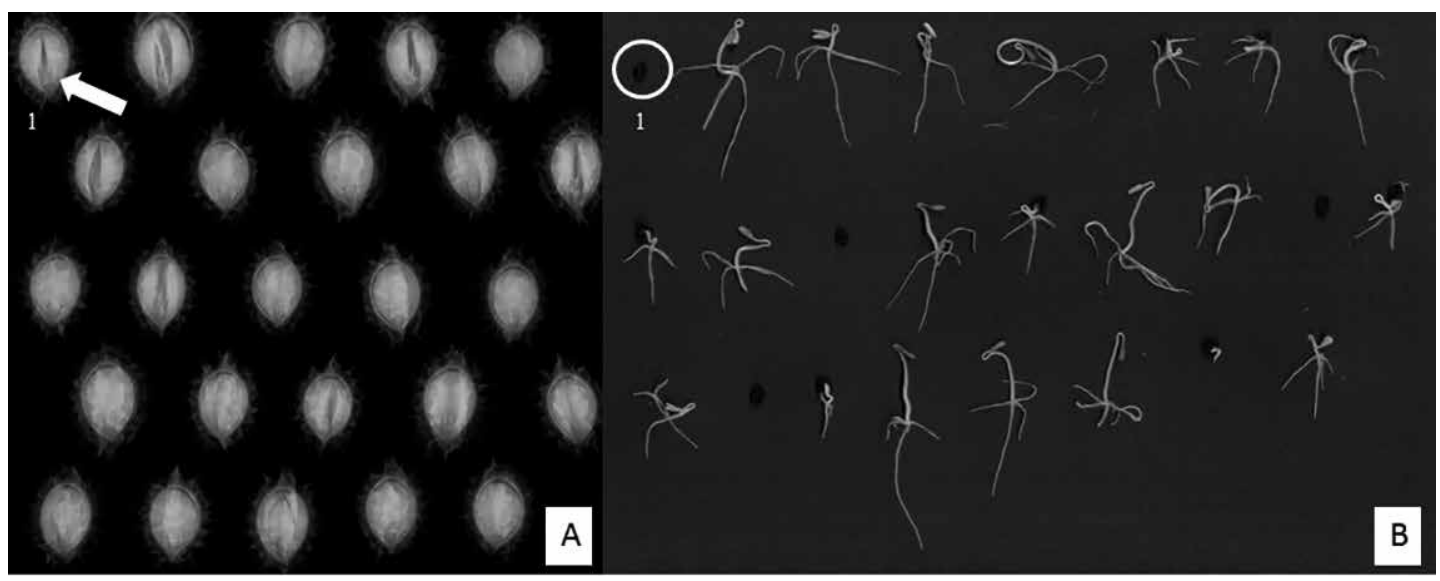

Figure 3. Radiographic image of papaya (Carica papaya L.) hybrid "Tainung 01" seeds extracted from the central portion of the fruits at the ripening stage 1 , showing the seed number 1 classified as "embryo easily visible" (EEV) (A), and result of the germination test of that seed 15 days after sowing (B).

example, for the seed number 1 (Figure 3A), which did not germinate in the germination test (Figure 3B). The non-germination could be probably explained by the occurrence of seed dormancy, according to what is illustrated on Figure 1D, where the seeds of the fruits at the ripening stage 1 had a higher proportion of dormant seeds, for both the central region and the extremities, especially in fruits at the ripening stages 3 and 5. Post harvest dormancy in papaya seeds has already been reported by several authors (Martins et al, 2006; Tokuhisa et al., 2007a) and can be attributed to the presence of inhibitors in the seed coat (sarcotesta and esclerotesta) and, or to the endogenous balance of promoter-inhibitor. Many studies are nowadays conducting in order to determine the factors involved in the dormancy of papaya seeds. In this sense, the application of X-ray test to assist in monitoring the quality of papaya seeds. In seeds of cucumber (Cucumis sativus L.) during fruit ripening, Nakada et al. (2011), found a close relationship between the results obtained in the X-ray images and results of the germination test.

From the radiographic images it was possible to quantify the percent of empty seeds and seeds with visible embryos (Figure 4). The length of seedling from seeds collected at the ripening stage 5 (Figure 4A) also increased and significantly differed from the other stages. Therefore, the results provided by the radiographic images indicate the potential use of the X-ray test to evaluate the quality of seed lots, determining the percent of empty or morphologically abnormal seeds. Empty seeds usually occur as a result of any deficiency in fertilization, caused by unfavorable environmental conditions during the development and maturation processes of seeds (Bewley and Black, 1994).

There were effects of the seed positioning within the fruits only for the following seeds apparently empty (Figure 4C). Higher values for these two variables were detected for both the seeds extracted from the central portion and from the extremities of the fruits, respectively, thus reinforcing the results of X-ray images (Figures 2 and 3), in which it was possible to observe a larger number of empty seeds among the ones extracted from the extremities of the fruits. Data on seedling length obtained from seeds removed from the central portion of the fruit showed higher values in relation to those obtained from the extremities (Figure 4D).

The germination also increased with increasing maturity, reaching their highest values for seeds removed from the central portion of the fruits at the ripening stages 3 and 5 and full maturation stage. In seeds of the extremities, higher germination percentage was observed at stages 5 and full maturation (Figure 5B). The seedling length (Figure 5C) was similar for the seeds from both locations within the fruit, only for the ripening stage 5. Comparing the different ripening stages, it was observed a larger seedling length at the ripening stage 5 on the seeds removed from the extremities of the fruit that differed significantly from the other ripening stages. It was 

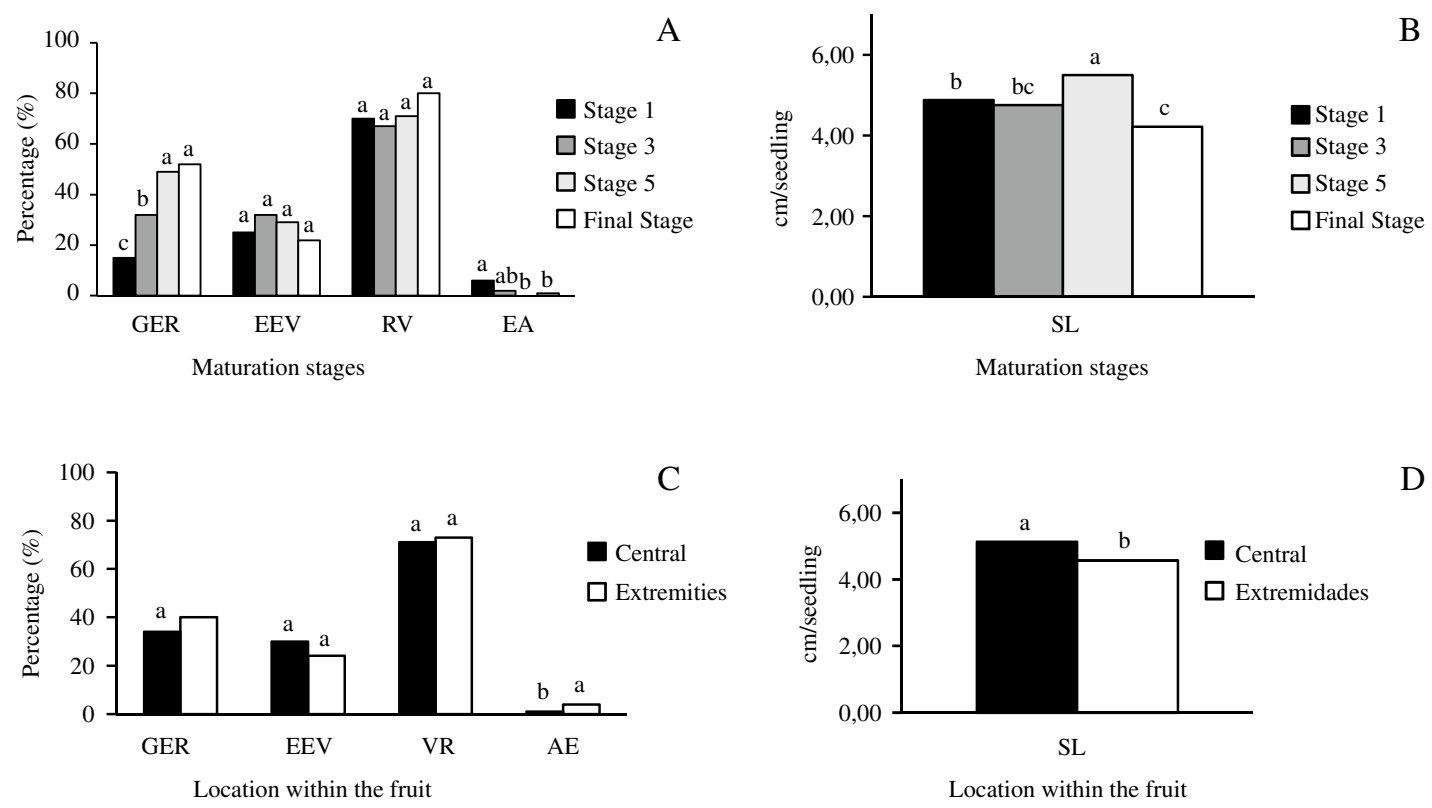

$\mathrm{D}$

Figure 4. Mean percentage data obtained for germination (GER), seeds with embryo easily visible (EEV), seeds with visible rootlet (VR), appeared empty seed (AE), and seedling length (SL) of papaya (Carica papaya L.) hybrid "Tainung 01", according to the maturation stages of the fruit (A and B); and location of the seeds within the fruit (C and D). Graph columns topped with the same letter are not statistically different by $\mathrm{F}$ test for the position of seeds within the fruit and Tukey test for the maturation stages, respectively, both at $5 \%$ probability.

also found no significant difference in the interaction between maturity stages and seed position within the fruit for the seeds with embryos easily visible (EEV) (Figure 5D), seeds with visible radicle (VR) (Figure 5E) and seeds apparently empty (AE) (Figure 5F). These seeds, although externally similar in appearance to be classified as viable, did not have either embryos normally developed or endosperm. Results achieved in this study confirm what had been previously verified by Pupim et al. (2008) and Souza et al. (2008), who also emphasized the efficiency of the X-ray test in assessing the quality of seeds of Cecropia pachystachya and Platypodium elegans, respectively, classifying them according to their internal morphology as filled, empty and damaged. Feitosa et al. (2009) found that the X-ray technique can be helpful in assessing the physical quality of seeds of the poor soil and hardwood wild Eremanthus erythropappus, while Pinto et al. (2009) applied the test in order to detect mechanical damages in soybean seed lots.

\section{Conclusions}

Papaya seeds of high physiological quality are obtained from the central position of the fruits in the ripening stage 5 and full maturation, corresponding to $75 \%$ and $100 \%$ ripeness. A higher proportion of dormant and empty seeds is verified in the extremities of fruits at the ripening stage 1 ( $25 \%$ ripeness). Seeds removed from the central portion of the fruits have better performance and fewer empty seeds than those removed from the extremities. The X-ray test is adequate to evaluate the papaya seeds quality, thus allowing for the distinction between empty seeds and seeds with normal embryo within a sample.

\section{Acknowledgements}

To CNPq for the financial support to this research, and to Sávio Cazelli Torezani for providing the papaya fruits. 

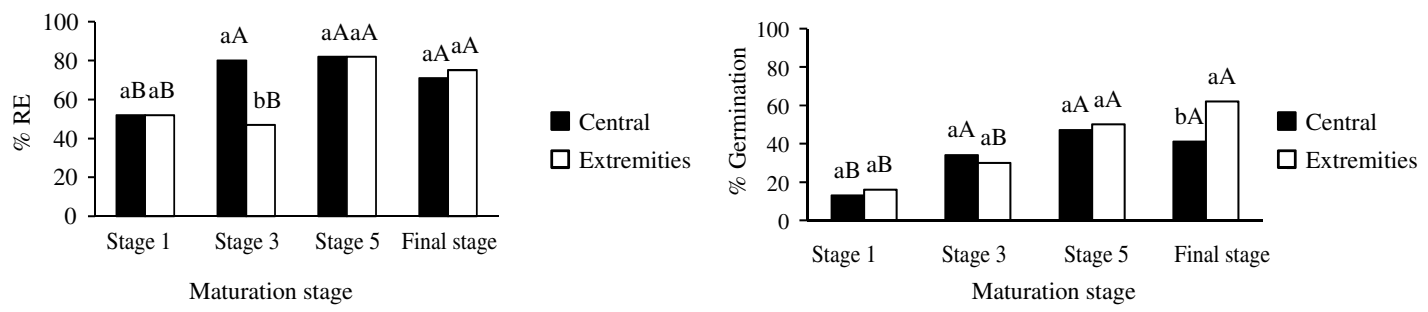

C

D
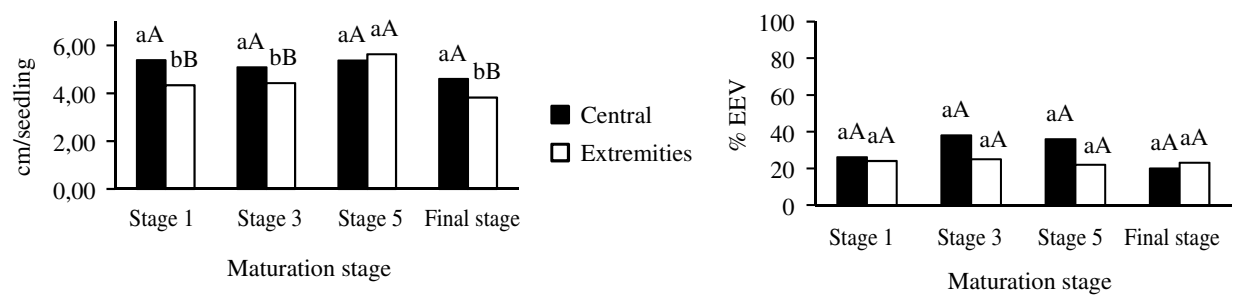

Central

Central

$\square$ Extremities

Maturation stage

E
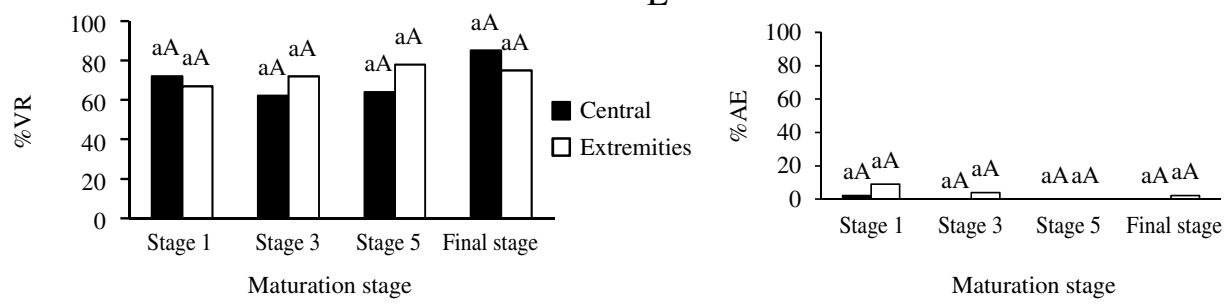

Central

$\square$ Extremities

Figure 5. Mean percentage data obtained for radicle emission (RE) (A), germination (B), and mean length of normal seedlings (cm/ seedling) (C), obtained from seeds subjected to the X-ray test; percent values extracted from the radiographic images showing seeds with embryo easily visible (EEV) (D), seeds showing visible radicle (VR) (E) and apparently empty seeds (AE) (F) in seed lots of papaya (Carica papaya L.) hybrid "Tainung 01", according to the maturation stages and location of seeds within the fruit. Means followed by lowercase letters on top of each graph column compare the location of seeds within the fruit at each ripening stage; uppercase letters compare each location among ripening stages. Graph columns topped with the same letter are not statistically different by $\mathrm{F}$ and Tukey tests at $5 \%$ probability, respectively.

\section{Literatura Citada}

AOSA. Association Of Offlcial Seed Analysts.

1983. Seed vigor testing handbook. East Lansing: AOSA, $93 \mathrm{p}$.

Aroucha, E.M.M.; Silva, R.F.; Oliveira, J.G.; Viana, A.P.; Gonzaga, M.P.

2005. Época de colheita e período de repouso dos frutos de mamão (Carica papaya L.) cv. Golden na qualidade fisiológica das sementes. Ciência Rural, 35: 537-543.

Bewley, J.D.; Black, M.

1994. Seeds. Physiology of Development and Germination. New York: Plenum Press, 445 p.

Brasil. Ministério da Agricultura, Pecuária e Abastecimento 2009. Regras para análise de sementes. Ministério da Agricultura, Pecuária e Abastecimento. Secretaria de Defesa Agropecuária. Brasília: MAPA/ACS, 2009. 395 p.
Craviotto, R.M.; Yoldjian, A.M.; Salina A.R.; Arango, M.R.; Bisaro, V.; Maturo, H.

2002. Description of pure seed fraction of oat through usual evaluations and radiographic images. Pesquisa Agropecuária Brasileira, 37: 1183-1188.

Dell Aquila, A.

2009. Development of novel techniques in conditioning, testing and sorting seed physiological quality. Seed Science and Technology, 37: 608-624.

Dias, D.C.F.S.; Ribeiro, F.P.; Dias, L.A.S.; Silva, D.J.H.; Vidigal, D.S.

2006. Tomato seed quality in relation to fruit maturation and post-harvest storage. Seed Science and Technology, 34: 691-699. 
Feitosa, S.S.; Davide, A.C.; Tonetti, O.A.O.; Fabricante, J.R.; Lui, J.J.

2009. Estudos de viabilidade de sementes de candeia Eremanthus erythropappus (DC) MacLeish por meio de testes de germinação e raios X. Floresta, 39: 393-399.

Martins, G.N.; Silva, R.F.; Pereira, M.G.; Araújo, E.F.; Posse, S.C.P. 2006. Influência do repouso pós-colheita de frutos na qualidade fisiológica de sementes de mamão. Revista Brasileira de Sementes, 28: 142-146.

Nagao, M.A.; Furutani, S.C.

1986. Improving germination of papaya seed by density separation, potassium nitrate, and gibberellic acid. HortScience, 21: 1439-1440.

Nakada, P.G.; Oliveira, J.A.; Melo, L.C.; Gomes, L.A.A.; Pinho, E.V.R.V.

2011. Desempenho fisiológico e bioquímico de sementes de pepino nos diferentes estádios de maturação. Revista Brasileira de Sementes, 33: 113-122.

Pinto, T.L.F.; Cicero, S.M.; França-Neto, J.B.; Forti, V.A. 2009. An assessment of mechanical and stink bug damage in soybean seed using X-ray analysis test. Seed Science and Technology, 37: 110-120.

Pupim, T.L.; Novembre, A.D.L.C.; Carvalho, M.L.M.; Cicero, S.M. 2009. Adequação do teste de raios X para avaliação da qualidade de sementes de embaúba (Cecropia pachystachya Trec.). Revista Brasileira de Sementes, 30: 28-32.
Silva, P.P.; Nascimento, W.M.

2010. Definição da metodologia para realização do teste de raios X em sementes de abóbora. Horticultura Brasileira, 28: 4273-4277.

Souza, L.A.; Reis, D.N.; Santos, J.P.; Davide, A.C.

2008. Uso de raios-x na avaliação da qualidade de sementes de Platypodium elegans. Revista Ciência Agronômica, 39: 343-347.

Tokuhisa, D.; Dias, D.C.F.S.; Alvarenga, E.M.; Dias, L.S.A.; Marin, S.L.D.

2007a Tratamentos para superação da dormência em sementes de mamão. Revista Brasileira de Sementes, 29: 131-139.

Tokuhisa, D.; Dias, D.C.F.S.; Alvarenga, E.M.; Hilst, P.C.;

Demuner, A.J.

2007b Compostos fenólicos inibidores da germinação em sementes de mamão (Carica papaya L.). Revista Brasileira de Sementes, 29: 161-168.

Vidigal, D.S., Dias; D.C.F.S., Naveira; D.S.P.C., Rocha; F.B.; Bhering, M.C.

2006. Qualidade fisiológica de sementes de tomate em função da idade e do armazenamento pós-colheita dos frutos. Revista Brasileira de Sementes, 28: 87-93.

Vidigal, D.S.; Dias, D.C.F.S.; Von Pinho, E.R.V.; Dias, L.A.S. 2009. Sweet pepper seed quality and lea-protein activity in relation to fruit maturation and post-harvest storage. Seed Science and Technology, 37: 192-201.

Vidigal, D.S.; Dias, D.C.F.S.; Dias, L.A.S.; Finger, F.L.

2011 Changes in seed quality during fruit maturation of sweet pepper. Scientia Agricola, 68: 535-539. 